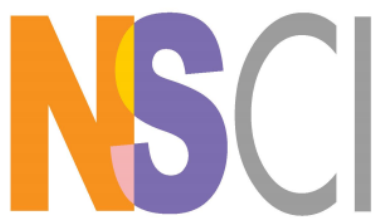

Current Perspectives on Medicinal and Aromatic Plants

An International Journal

ISSN: 2619-9645 | e-ISSN: 2667-5722

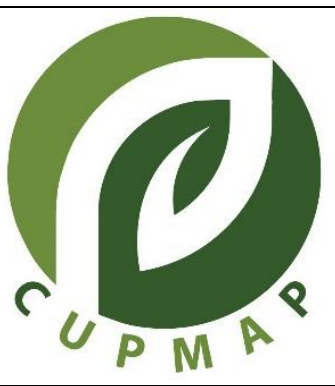

\title{
Characterization of Origanum vulgare SUBSP. hirtum (LINK) Iestwaart Population and Determination of A Clones
}

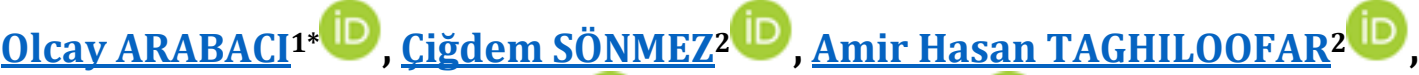 \\ $\underline{\text { Ŭur TAN }}^{1}$ iD, Emine BAYRAM ${ }^{2}$
}

${ }^{* 1}$ Field Crops Department, Agricultural Faculty, Adnan Menderes University, Aydın-Turkey

2 Field Crops Department, Agricultural Faculty, Ege University, İzmir-Turkey

*Corresponding author : oarabaci@adu.edu.tr

Received : 28/11/2019

Accepted : 26/12/2019

\begin{abstract}
Identification of the high yielding and the good quality clones of one population (B population) of Origanum vulgare subsp. hirtum (Link) Iestwaart was one of the purposes in this study and furthermore some agronomic and quality characteristics of individual plants were examined during two years (2014-2015). Annual performances were determined according to the minimum and maximum values of the first, second and non-flowering harvests of the population. Also for second year, minimum, maximum and mean values of the individual plants of the population were stated in the paper. The aim was to reveal if the high yield and quality characteristics of plants are based on the genotype. Individual plants of the B population, the mean plant height was found as $39 \mathrm{~cm}$, canopy value as $30.5 \mathrm{~cm}$, Fresh herb yield as $167.9 \mathrm{~g} /$ plant, Drog herb yield as $65.5 \mathrm{~g} / \mathrm{plant}$, Drog leaves yield as $32.2 \mathrm{~g} / \mathrm{plant}$ and the mean rate of the essential oil as $4,01 \%$. Considering the two years' results of the B population, A clones were created in 2016 by selecting the high yielding and of good quality genotypes. On A clones, the plant height, fresh herb yield, Drog herb yield, essential oil rate and essential oil yield values were determined between $13-52.5 \mathrm{~cm}, 8-624 \mathrm{~g} / \mathrm{plot}, 4-218.4$ g/plot, $1.6-100.1 \mathrm{~g} /$ plot, $1.08-7.92 \%$ and $0.03-5.74 \mathrm{~L} /$ parcel, respectively.
\end{abstract}

Key Words: Origanum vulgare subsp. hirtum, Population, Selection, Yield, Essential Oil, Compound

(c) CUPMAP. All rights reserved.

\section{Introduction}

The importance of the medicinal plants and herbs increases day by day. In Turkey, a great majority of these plants are being picked up from the nature; consequently, environmental destruction and the loss of some endemic species are inevitable. The primary of these plants is oregano which is being picked from the flora and has a crucial role in export. In Turkey, the genus involving different types of oregano are Origanum,
Thymbra, Thymus, Coridothymus and Satureja. The species which are exported most and used in the production of essential oils are Origanum onites, Origanum vulgare subsp. hirtum, Origanum minutiflorum, Origanum majorana and Origanum syriacum var. bevanii. Beside these, other traded species are Coridothymus capitatus, Thymbra spicata, Thymbra sintenissii, Satureja cuneifolia, Satureja hortensis, Satureja montana, Satureja spicigera and Thymus eigii'. The common quality of all these species 
is containing essential oils and the main components of their essential oils are Carvacrol or Thymol (Başer, 2001; Hayta and Arabacl, 2011). Recently, Lukas et al. (2013) indicated that Origanum dubium and Origanum majorana should be better classified as different species even though they are morphologically similar. Marjoram, which has been known as 0 . majorana so far, actually belongs to the species $O$. dubium. In Turkey, the most valuable oregano species belong to the genus Origanum in economical and agricultural fields.

In Turkey, approximately $80 \%$ of the oregano which is still exported is cultivated under field conditions, $20 \%$ is picked up from the nature (Bayram et al. 2010). Oregano picked up from the nature belong to the various genuses and species such as Coridothymus capitatus, Thymbra spicata, Origanum onites, Origanum syriacum, Origanum majorana, Origanum minutiflorum and Origanum vulgare subsp. hirtum (TSI, 2004). Cultivated oregano species are Origanum onites and Origanum vulgare subsp. hirtum which are mainly grown in Marmara, Mediterranean and Aegean Regions.

This study is done with the purpose of the characterization of selected promising plants at the B clone of Origanum vulgare subsp. hirtum (Link) Iestwaart and the development of new types with higher Drog yields and essential oil rates using the clone selection method.

\section{Material and Method}

The seeds of B population is used in study that is one of the five promising populations (A,B,C,D and E). All populations were selected from the Origanum vulgare subsp. hirtum (Link) Iestwaart plants. The study carried out in Aydin ecological conditions. The B population is originated from the south east exposure of the Ida Mountains with the altitude of $559 \mathrm{~m}$ and the mapping coordinates of 545202-4423405.
The field study of the experiment was carried out on the area of the Research and Practice Farm of the Adnan Menderes University, Faculty of Agriculture. The individual plants were investigated during the years of 20132014 and 2014-2015 and A clones were cultivated during the year 2016. Study field has typical Mediterranean climate conditions, the total precipitation of long years is $636,7 \mathrm{~mm}$ and the average temperature is $17,7^{\circ} \mathrm{C}$. The soil texture of the study area was sandy-loam, $\mathrm{pH}$ value is 8.43 and the ratio of the organic substances were $1.30 \%$.

The seeds of the B population were sown in $06 / 12 / 2013$ on the seedbeds in a greenhouse and the germination was observed in $17 / 12 / 2013$. When plants have proper maturity (8-10 $\mathrm{cm}$ seedlings), to create the individual plants, 648 seedlings were planted to an area of $129.6 \mathrm{~m}^{2}$ with a planting level of $50 \times 40 \mathrm{~cm}$ in $02 / 04 / 2014$. The flowering individual plants of the population were harvested in 10-18/07/2014 and in $10 / 09 / 2014$ during the first year. Some plants were harvested once and some of them were harvested twice. While the plants were harvesting (10-18/07/2014 and $10 / 09 / 2014$ ), some of the individual plants of population B haven't flowered so the harvesting could not be performed on these plants. To determine the annual growth and yield performance of the individual plants for the first year, just after identifying the morphological characteristics of the plants without taking the flowering or nonflowering into account they were harvested between the dates of $14-20 / 10 / 2014$ and 04$07 / 11 / 2014$. During the harvest between these dates even some plants have reached to the maturity for a third harvest. In order to determine the individual plants those have good quality features, observations and measurements were repeated for two years. The harvestings of the second year were done on the dates $24 / 06 / 2015$ and $07 / 07 / 2015$. 
The analyses of the essential oil were performed in the Medicinal Plants Laboratories of Adnan Menderes University and Ege University Agriculture Faculties. The essential oil rates of the study were determined volumetrically on the air dried leaves samples using the Neo Clevenger apparatus. The essential oil rates are stated as milliliter /100 $\mathrm{g}(\%)$ on air dried leaves (Wichtl, 1971).

Among the plants on the field, the promising individual ones were identified from $B$ popultions to form A clones considering the results of the yield of leaves and essential oil of two years and The superior 140 genotypes were selected.

From 140 selected genotypes, for each genotype the 10 cuttings planted in the greenhouse between 03-05/12/2015. Nevertheless, upon determining that four genotypes are not suitable for the vegetative reproduction so final number of the genotypes planted on the field was 136. After rooting of cuttings, between dates of 06/04/2016 and 07/04/2016, the A clone cuttings were planted to the $2 \mathrm{~m}^{2}$ plots with a planting density of $50 \times 40 \mathrm{~cm}$ and 10 plants belonging to the each row. So the A clones were created. On the third year of the trial, all the crop care was performed properly on the A clones. The observations and measurements were done firstly and after that the first and last plants of each clone were left as the border effect and the remaining plants were harvested on 27/06/2016.

The essential oil components were determined with GC-MS (Shimadzu 2010 Plus QP-5050 Quadrapole Detector) at the SDU Experimental and Observational Research and Application Center. GC-MS operating conditions were carried out as follows: CP-Wax 52 CB (50 m x $0.32 \mathrm{~mm}, 0.25$ $\mu \mathrm{m})$ capillary column was used, column temperature was initially $60^{\circ} \mathrm{C}$, then gradually increased to $220^{\circ} \mathrm{C}$ at $10^{\circ} \mathrm{C} / \mathrm{min}$ and waited for 10 minutes at $220^{\circ} \mathrm{C}$. The total analysis time was 60 minutes, the injector temperature was $240^{\circ} \mathrm{C}$ and the detector temperature was $250^{\circ} \mathrm{C}$. Helium $(20 \mathrm{~mL} / \mathrm{min}$, split 1:20) gas was used as the carrier gas. 7.5 $\mu \mathrm{l}$ of the sample was diluted by adding 1500 $\mu \mathrm{l}$ of dichloromethane. Wiley, Nist, Tutor, FFNSC libraries were used to identify the essential oil components.

The findings were evaluated statistically using the SPSS (SPSS 17.0 2008) and TOTEMSTAT (Acikgoz et al., 2004) programs.

\section{Results}

The statistical findings of the two years (2013-2015 growth years) which belong to the individual plants of the B population of $O$. vulgare subsp. hirtum (Link) Iestwaart grown under Aydin ecological conditions and A clones created from these population were stated below;

\subsection{Individual plants}

Within 648 individual plants, 581 plants were reached maturity for harvest. The first year of the study, flowering was viwed on the 208 plants of the $B$ population and the harvesting was done for those individual plants. Some statistical analyses of the characteristics belonging to the first harvest of the B population are shown on Table 1 . According to the mean values, plant height, canopy value, Fresh herb yield, drog herb yield, drog leaves yield and essential oil rate have been determined as 35.3, 17.8, 56 $\mathrm{g} / \mathrm{plant}, 21 \mathrm{~g} /$ plant, $14.6 \mathrm{~g} /$ plant and $4.15 \%$, respectively. It was observed that after the first harvest, some of the individual plants of the B population kept growing and some plants have had second flowering so the second harvest were made with those 11 flowering individual plants. The plant height of the harvested plants was $28-67 \mathrm{~cm}$, canopy value $20-36$, fresh herb yield $8-83 \mathrm{~g} /$ plant, drog leaves yield 3.95- $47.58 \mathrm{~g} / \mathrm{plant}$ and the essential oil rate varied between $3-4.7 \%$ (Table 2). 
Table 1. Statistical values for the first year (2014) I. harvest of the individual plants of B population Origanum vulgare subsp. hirtum

\begin{tabular}{ccccccccc}
\hline Chracteristics & $\begin{array}{l}\text { Number } \\
\text { of Plants }\end{array}$ & Minimum & Maximum & Mean & Variance & $\begin{array}{c}\text { Standard } \\
\text { deviation }\end{array}$ & $\mathbf{S}^{\bar{x}}$ & CV \\
\hline $\begin{array}{c}\text { Plant Height } \\
\text { (cm) }\end{array}$ & 208 & 14.000 & 50.000 & 35.327 & 50.7235 & 7.1220 & 0.4938 & 20.1604 \\
$\begin{array}{c}\text { Canopy Value } \\
\text { (cm) }\end{array}$ & 208 & 3.000 & 45.000 & 17.827 & 51.6704 & 7.1882 & 0.4984 & 40.3222 \\
$\begin{array}{c}\text { Fresh Herb } \\
\text { Yield (g/plant) }\end{array}$ & 208 & 12.000 & 185.000 & 55.966 & 776.5931 & 27.8674 & 1.9323 & 49.7932 \\
$\begin{array}{c}\text { Drog Herb } \\
\text { Yield (g/plant) } \\
\begin{array}{c}\text { Drog Leaves } \\
\text { Yield (g/plant) }\end{array}\end{array}$ & 208 & 2.000 & 90.000 & 21.000 & 144.7826 & 12.0326 & 0.8343 & 57.2979 \\
$\begin{array}{c}\text { Essential Oil } \\
\text { Rate (\%) }\end{array}$ & 208 & 1.110 & 42.240 & 14.636 & 58.5139 & 7.6494 & 0.5304 & 52.2653 \\
\hline
\end{tabular}

Table 2. Statistical values for the first year (2014) II. harvest of the individual plants of B population Origanum vulgare subsp. hirtum

\begin{tabular}{cllllllll}
\hline Characteristics & $\begin{array}{l}\text { Number of } \\
\text { Plants }\end{array}$ & Minimum & Maximum & Mean & Variance & $\begin{array}{l}\text { Standard } \\
\text { deviation }\end{array}$ & $\mathbf{S}^{\bar{x}}$ & CV \\
\hline $\begin{array}{c}\text { Plant Height (cm) } \\
\text { Canopy Value }\end{array}$ & 11 & 28.000 & 67.000 & 44.273 & 178.4182 & 13.3573 & 4.0274 & 30.1706 \\
$\begin{array}{c}\text { (cm) } \\
\begin{array}{c}\text { Fresh Herb Yield } \\
\text { (g/plant) }\end{array}\end{array}$ & 11 & 20.000 & 36.000 & 29.182 & 38.5636 & 6.2100 & 1.8724 & 21.2802 \\
$\begin{array}{c}\text { Drog Herb Yield } \\
\text { (g/plant) }\end{array}$ & 11 & 17.000 & 200.000 & 97.091 & 4961.0909 & 70.4350 & 21.2370 & 72.5454 \\
$\begin{array}{c}\text { Drog Leaves Yield } \\
\text { (g/plant) }\end{array}$ & 11 & 8.000 & 83.000 & 40.455 & 859.0727 & 29.3099 & 8.8373 & 72.4515 \\
$\begin{array}{c}\text { Essential Oil Rate } \\
\text { (\%) }\end{array}$ & 11 & 3.950 & 47.580 & 24.239 & 311.8603 & 17.6596 & 5.3246 & 72.8557 \\
\hline
\end{tabular}

When table 3 was examined, it was seen that 530 individual non-flowering plants were harvested in the first year. On this harvest, plant height varied between $12-67 \mathrm{~cm}$ and the mean value has been $32.4 \mathrm{~cm}$. The minimum and maximum canopy values were $20 \mathrm{~cm}$ and $73 \mathrm{~cm}$, respectively and the mean canopy value was found as $44.7 \mathrm{~cm}$. The yield of the fresh herb varied between 20-699 $\mathrm{g} / \mathrm{plant}$ and the mean yield was 229.85 .
Minimum drog herb yield was $4 \mathrm{~g} /$ plant, maximum herb yield was $262 \mathrm{~g} /$ plant and the mean yield has been $88.75 \mathrm{~g} /$ plant whereas yield of drog leaves varied between 3.3$119.79 \mathrm{~g} /$ plant and the mean leaves yield has been found as $41.13 \mathrm{~g} /$ plant. Minimum and maximum essential oil rates of the plants were $0.2 \%$ and $2.5 \%$, respectively and the mean value was stated as $1.26 \%$. 
Table 3. Statistical values for the first year (2014) non flowering harvest of the individual plants of B population Origanum vulgare subsp. hirtum

\begin{tabular}{clllccccc}
\hline Characteristics & $\begin{array}{l}\text { Number } \\
\text { of } \\
\text { Plants }\end{array}$ & Minimum & Maximum & Mean & Variance & $\begin{array}{l}\text { Standard } \\
\text { deviation }\end{array}$ & $\mathbf{S}^{\overline{\boldsymbol{x}}}$ & $\mathbf{C V}$ \\
\hline $\begin{array}{c}\text { Plant Height } \\
\text { (cm) }\end{array}$ & 530 & 12.000 & 67.000 & 32.389 & 93.7050 & 9.6801 & 0.4205 & 29.8874 \\
$\begin{array}{c}\text { Canopy Value } \\
\text { (cm) }\end{array}$ & 530 & 20.000 & 73.000 & 44.740 & 78.4992 & 8.8600 & 0.3849 & 19.8034 \\
$\begin{array}{c}\text { Fresh Herb } \\
\text { Yield (g/plant) }\end{array}$ & 530 & 20.000 & 699.000 & 229.847 & 11591.6609 & 107.6646 & 4.6767 & 46.8418 \\
$\begin{array}{c}\text { Drog Herb } \\
\text { Yield (g/plant) }\end{array}$ & 530 & 4.000 & 262.000 & 88.745 & 1679.1430 & 40.9773 & 1.7799 & 46.1740 \\
$\begin{array}{c}\text { Drog Leaves } \\
\text { Yield (g/plant) }\end{array}$ & 530 & 3.300 & 119.790 & 41.132 & 395.9682 & 19.8989 & 0.8644 & 48.3780 \\
$\begin{array}{c}\text { Essential 0il } \\
\text { Rate (\%) }\end{array}$ & 530 & 0.200 & 2.500 & 1.264 & 0.1375 & 0.3708 & 0.0161 & 29.3280 \\
\hline
\end{tabular}

Table 4. Statistical values for the second year (2015) harvest of the individual plants of B population Origanum vulgare subsp. hirtum

\begin{tabular}{ccccccccc}
\hline Characteristics & $\begin{array}{l}\text { Number } \\
\text { of } \\
\text { Plants }\end{array}$ & Minimum & Maximum & Mean & Variance & $\begin{array}{l}\text { Standard } \\
\text { deviation }\end{array}$ & $\mathbf{S}^{\overline{\boldsymbol{x}}}$ & CV \\
\hline $\begin{array}{c}\text { Plant Height } \\
\text { (cm) }\end{array}$ & 581 & 9.000 & 85.000 & 40.738 & 219.2107 & 14.8058 & 0.6142 & 36.3435 \\
$\begin{array}{c}\text { Canopy Value } \\
\text { (cm) }\end{array}$ & 581 & 7.000 & 55.000 & 30.306 & 94.7715 & 9.7351 & 0.4039 & 32.1222 \\
$\begin{array}{c}\text { Fresh Herb } \\
\text { Yield (g/plant) }\end{array}$ & 581 & 7.000 & 925.000 & 208.098 & 25474.2093 & 159.6064 & 6.6216 & 76.6977 \\
$\begin{array}{c}\text { Drog Herb } \\
\text { Yield (g/plant) }\end{array}$ & 581 & 3.000 & 407.000 & 80.972 & 4027.9406 & 63.4661 & 2.6330 & 78.3798 \\
$\begin{array}{c}\text { Drog Leaves } \\
\text { Yield (g/plant) }\end{array}$ & 581 & 1.620 & 170.700 & 37.791 & 751.8826 & 27.4205 & 1.1376 & 72.5580 \\
$\begin{array}{c}\text { Essential 0il } \\
\text { Rate (\%) }\end{array}$ & 581 & 1.800 & 8.500 & 4.991 & 0.9451 & 0.9722 & 0.0403 & 19.4777 \\
\hline
\end{tabular}

On the second year of the study, 581 individual plants were harvested. Some statistical values of the second year are shown on table 4. The plant height varied between $9-85 \mathrm{~cm}$ and the mean value was determined as $40.7 \mathrm{~cm}$. The mean canopy value was $30.3 \mathrm{~cm}$, minimum and maximum values have been 7 and $55 \mathrm{~cm}$, respectively.
The mean values of fresh herb yield, drog herb yield and drog leaves yield has been $208.1 \mathrm{~g} / \mathrm{plant}, 80.97 \mathrm{~g} / \mathrm{plant}$ and 37.79 $\mathrm{g} /$ plant, respectively. The minimum essential oil rate was $1.8 \%$ whereas the maximum value was $8.5 \%$ and the mean value was $4.99 \%$ (Table 4). 
Table 5. Mean harvest values (2014-2015) of the individual plants of B population Origanum vulgare subsp. hirtum for two years

\begin{tabular}{cllllll}
\hline Characteristics & $\begin{array}{l}\text { 1.Year } \\
\text { I. Harvest }\end{array}$ & $\begin{array}{l}\text { 1.Year } \\
\text { II. Harvest }\end{array}$ & $\begin{array}{l}\text { 1.Year } \\
\text { Non } \\
\text { Flowering } \\
\text { Harvest }\end{array}$ & $\begin{array}{l}\text { 1.Year } \\
\text { Mean } \\
\text { Harvest } \\
\text { Values }\end{array}$ & $\begin{array}{l}\text { 2.Year } \\
\text { Harvest }\end{array}$ & $\begin{array}{l}\text { Mean } \\
\text { Values for } \\
\text { Two Years }\end{array}$ \\
\hline $\begin{array}{c}\text { Plant Height } \\
\text { (cm) }\end{array}$ & 35.327 & 44.273 & 32.389 & 37.330 & 40.738 & 39.034 \\
$\begin{array}{c}\text { Canopy Value } \\
\text { (cm) }\end{array}$ & 17.827 & 29.182 & 44.740 & 30.583 & 30.306 & 30.445 \\
$\begin{array}{c}\text { Fresh Herb Yield } \\
\text { (g/plant) }\end{array}$ & 55.966 & 97.091 & 229.847 & 127.635 & 208.098 & 167.867 \\
$\begin{array}{c}\text { Drog Herb Yield } \\
\text { (g/plant) }\end{array}$ & 21.000 & 40.455 & 88.745 & 50.067 & 80.972 & 65.520 \\
$\begin{array}{c}\text { Drog Leaves Yield } \\
\text { (g/plant) }\end{array}$ & 14.636 & 24.239 & 41.132 & 26.669 & 37.791 & 32.230 \\
$\begin{array}{c}\text { Essential Oil Rate } \\
\text { (\%) }\end{array}$ & 4.147 & 3.700 & 1.264 & 3.037 & 4.991 & 4.014 \\
\hline
\end{tabular}

The mean values of the two years of the examined characteristics of $\mathrm{B}$ population were shown on table 5 . The plant height was found as $39 \mathrm{~cm}$, canopy value as $30.4 \mathrm{~cm}$, fresh herb yield as $167.9 \mathrm{~g} / \mathrm{plant}$, drog herb yield as $65.5 \mathrm{~g} /$ plant, drog leaves yield as 32.2 $\mathrm{g} / \mathrm{plant}$ and the mean rate of the essential oil has been $4 \%$.

Table 6. Statistical values of some characteristics of A clone belonging to the B population Origanum vulgare subsp. hirtum

\begin{tabular}{ccccccccc}
\hline Characteristics & $\begin{array}{l}\text { Number } \\
\text { of } \\
\text { Plants }\end{array}$ & Minimum & Maximum & Mean & Variance & $\begin{array}{c}\text { Standard } \\
\text { deviation }\end{array}$ & $\mathbf{S}^{\bar{x}}$ & CV \\
\hline $\begin{array}{c}\text { Plant Height } \\
\text { (cm) }\end{array}$ & 136 & 13.000 & 52.500 & 33.567 & 85.233 & 9.232 & 0.792 & 27.504 \\
$\begin{array}{c}\text { Fresh Herb } \\
\text { Yield (g/plant) }\end{array}$ & 136 & 8.000 & 624.000 & 186.965 & 22655.392 & 150.517 & 12.907 & 80.506 \\
$\begin{array}{c}\text { Drog Herb } \\
\text { Yield (g/plant) }\end{array}$ & 136 & 4.000 & 218.400 & 68.660 & 2706.207 & 52.021 & 4.461 & 75.767 \\
$\begin{array}{c}\text { Drog Leaves } \\
\text { Yield (g/plant) }\end{array}$ & 136 & 1.600 & 100.100 & 31.689 & 423.865 & 20.588 & 1.765 & 64.968 \\
$\begin{array}{c}\text { Rate of Leaves- } \\
\text { Stem (\%) }\end{array}$ & 136 & 20.800 & 80.000 & 52.056 & 183.635 & 13.551 & 1.162 & 26.032 \\
$\begin{array}{c}\text { Essential Oil } \\
\text { Rate (\%) }\end{array}$ & 136 & 1.080 & 7.920 & 4.529 & 1.674 & 1.294 & 0.111 & 28.568 \\
$\begin{array}{c}\text { Essential Oil } \\
\text { Yield (g/plot) }\end{array}$ & 136 & 0.030 & 5.740 & 1.534 & 1.286 & 1.134 & 0.097 & 73.942 \\
\hline
\end{tabular}


Table 7. Essential oil Components of A clones in B Population (\%)

\begin{tabular}{|c|c|c|c|c|c|c|c|c|c|c|}
\hline \multicolumn{11}{|c|}{ Component Names and Ratios (\%) } \\
\hline $\begin{array}{l}\text { Clone } \\
\text { No }\end{array}$ & $\begin{array}{l}\text { TCC * } \\
\text { (Quanti } \\
\text { ty) }\end{array}$ & $\begin{array}{l}\alpha- \\
\text { Pinene }\end{array}$ & $\begin{array}{l}\text { 2- } \beta \text { - } \\
\text { Pinene }\end{array}$ & $\begin{array}{l}\beta- \\
\text { Myrcen } \\
\text { e }\end{array}$ & $\begin{array}{l}\alpha- \\
\text { Terpin } \\
\text { ene }\end{array}$ & $\begin{array}{l}\rho- \\
\text { Cymene }\end{array}$ & $\begin{array}{l}\gamma^{-} \\
\text {Terpin } \\
\text { ene }\end{array}$ & Thymol & $\begin{array}{l}\text { Carvacr } \\
\text { ol }\end{array}$ & $\begin{array}{l}\text { Essenti } \\
\text { al Oil } \\
\text { Ratio } \\
(\%)\end{array}$ \\
\hline B-4 & 11 & 0.85 & 1.53 & - & - & 3.55 & 14.44 & 0.04 & 76.91 & 6.83 \\
\hline B-20 & 12 & 1.45 & 2.14 & - & 1.54 & 3.68 & 11.32 & 0.16 & 76.64 & 6.25 \\
\hline B-70 & 16 & 0.37 & 1.06 & - & 0.74 & 2.93 & 6.36 & 0.12 & 84.45 & 5.50 \\
\hline B-102 & 13 & - & 1.64 & - & 1.32 & 3.47 & 13.59 & 0.28 & 76.52 & 6.92 \\
\hline B-183 & 18 & 0.62 & 0.04 & 1.18 & 0.89 & 2.80 & 5.99 & 0.07 & 83.48 & 5.75 \\
\hline B-201 & 15 & 1.29 & - & 1.55 & 0.70 & 3.42 & 3.85 & 0.17 & 84.95 & 5.75 \\
\hline B-296 & 14 & 1.16 & - & 1.43 & 0.87 & 3.26 & 3.72 & 0.16 & 86.02 & 5.50 \\
\hline B-342 & 11 & 2.80 & - & 2.53 & 2.72 & 8.54 & 16.67 & 0.71 & 62.17 & 5.75 \\
\hline B-345 & 15 & 1.39 & 2.09 & - & & 3.87 & 13.25 & 0.02 & 75.97 & 6.00 \\
\hline B-368 & 14 & 0.93 & - & 1.43 & 1.21 & 3.30 & 9.67 & 0.11 & 80.89 & 7.25 \\
\hline B- $413^{* *}$ & 10 & 0.19 & - & - & 2.72 & 1.51 & 0.13 & - & 92.14 & 5.13 \\
\hline B-414 & 12 & 0.77 & 1.14 & - & 0.80 & 3.24 & 5.21 & 0.03 & 86.01 & 5.42 \\
\hline B-417 & 12 & 0.60 & 1.35 & - & - & 3.31 & 6.70 & 0.08 & 83.90 & 6.33 \\
\hline B-423 & 13 & 0.84 & 1.10 & - & 0.83 & 3.08 & 4.41 & 0.05 & 87.00 & 5.46 \\
\hline B-430 & 15 & 0.60 & - & 1.12 & 1.11 & 2.87 & 8.77 & 0.03 & 83.12 & 5.58 \\
\hline B-446 & 50 & 0.47 & - & 1.14 & 0.56 & 2.54 & 2.73 & 0.03 & 86.92 & 6.33 \\
\hline B-447 & 16 & 0.49 & 1.20 & - & 0.55 & 1.92 & 3.08 & 0.11 & 88.50 & 6.67 \\
\hline B-458 & 12 & 0.41 & - & 0.78 & - & 2.68 & 3.11 & 0.16 & 89.92 & 5.25 \\
\hline B-466 & 8 & 3.27 & 3.66 & - & - & - & 21.51 & 0.21 & 69.99 & 5.92 \\
\hline B-575 & 15 & 1.45 & 2.08 & - & - & 4.68 & 13.26 & 0.04 & 74.06 & 5.33 \\
\hline
\end{tabular}

* Total Components Contents $=$ TCC

** The B-413 clone also contains 2.05\% Alloaromadendrene.

\subsection{A clones}

The findings of the variance, standard deviation, mean values and coefficient variation of the A clone were shown on table 6. According to the results of the statistical analyses, the minimum and maximum values have been determined for plant height 1352.5, for fresh herb yield 8-624 g/plot, for drog herb yield 4-218.4 g/plot, for drog leaves yield $1.60-100.1 \mathrm{~g} /$ plot, for the ratio of leaf-stem $20.8-80 \%$, for the essential oil rate $1.08-7.92 \%$ and for the essential oil yield 0.03-5.74 g/plot. On the other hand, coefficient variation has been found significantly high for the characteristics of fresh herb yield, drog herb yield, drog leaves yield and essential oil yield.

From each A clones, 20 clones have the maximum values or higher values than the average for the characteristics of fresh herb yield, drog herb yield, drog leaves yield and essential oil rate were selected for the further research.

\section{Discussion}

According to the years, some growth variations are observed on the individual plants. Second year of plant development, root system develop better and vegetation period is longer so an increased yield could be expected.

A wide variation was identified among the examined B population. A similar situation was stated on the studies of Ceylan et al. (2003) examined yield potential and essential oil composition of Origanum onites L. clones and individual plants and Arabacı et al. (2012) who studied on the ontogenetic variability of Coridothymus capitatus L. genotypes. Our results are in accordance with 
the findings of the researchers. While the plant height values of the study are similar to the values of Žukauska (2001) as $47-53 \mathrm{~cm}$ from nature, $32-93 \mathrm{~cm}$ cultivated, Oflaz et al. (2002) as 75-80 cm, W'glarz et al. (2006) as 54-68 cm and Ahmad et al. (2008) as 25.45$55.58 \mathrm{~cm}$. Our maximum plant height values are close to the cultivated plant heights of Žukauska (2001).
Žukauska (2001) obtained a fresh herb yield of $82-915 \mathrm{~g} / \mathrm{m}^{2}$ from the natural area of Latvia, fresh herb yields of cultivated population of this plants have been for the first, second and third years $113-1050 \mathrm{~g} / \mathrm{m}^{2}$, $125-2135 \mathrm{~g} / \mathrm{m}^{2}$ and $516-2414 \mathrm{~g} / \mathrm{m}^{2}$, respectively. Our fresh herb yields have similarity to the results of the researcher.

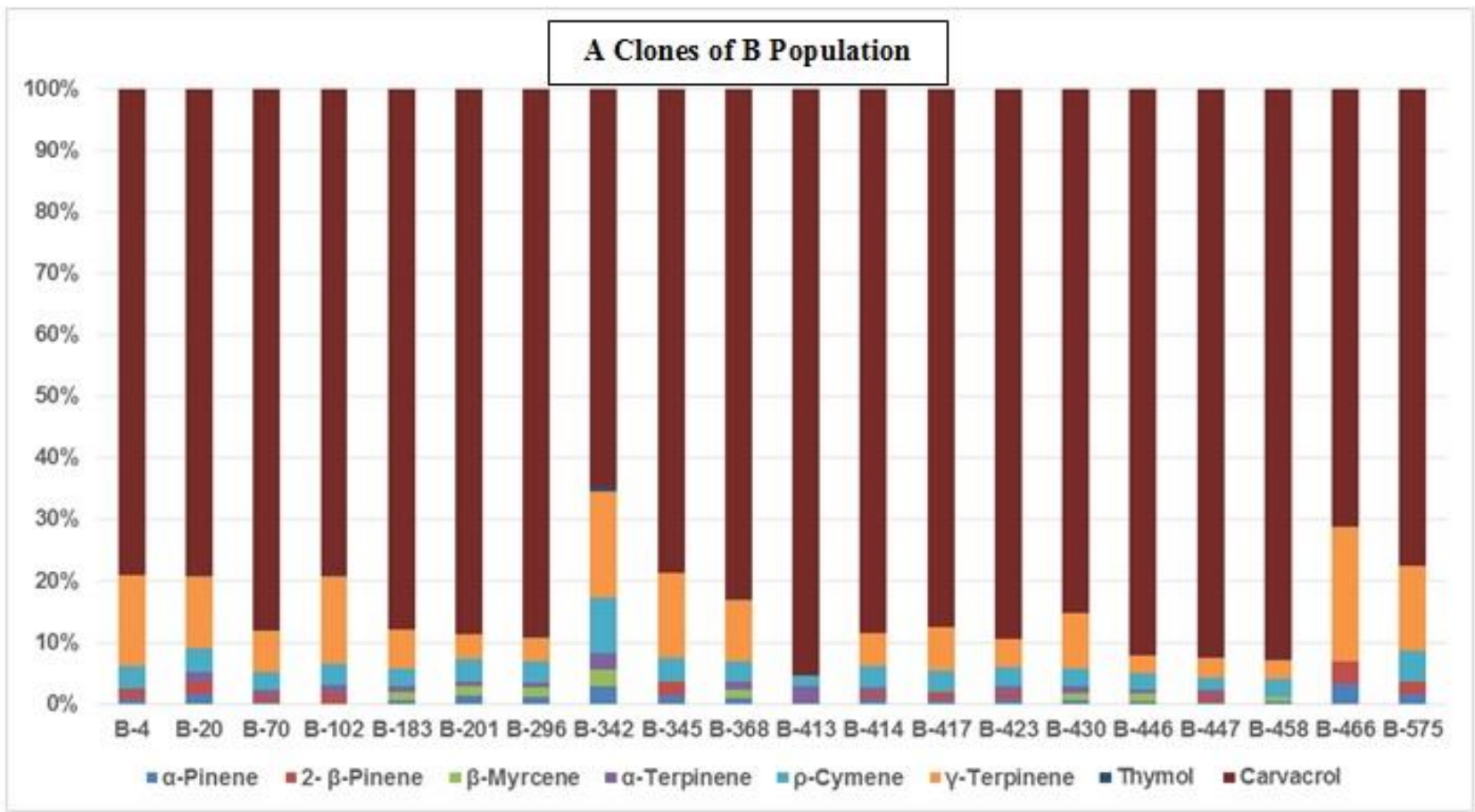

Figure 1. Distribution of Essential Oil Components of A Clones for Population B (\%)

Leto and Salamone (1996) reported that the drog herb yield of the natural population varies between 105-1100 g/plant. W'glarz et al. (2006) stated that the values for this characteristic are between 243.1-636.6 g for a single plant. While the findings we obtained from our research are in the range of the findings of W'glarz et al. (2006), they have low values compared to the maximum values of Leto and Salamone (1996).

Kokkini (1996) reported that the essential oil yield of 0 . vulgare subsp. hirtum samples from different locations were between 1-1.6 $\mathrm{ml} / 100 \mathrm{~g}$. Tinmaz et al. (2002) determined the quality characteristics of $O$. vulgare subsp. hirtum from various cities of Marmara Region and they observed that the essential oil rate increases when the plants are transferred to a cultivated area from nature. Study also has mentioned that the maximum essential oil yield was $12.3 \mathrm{~kg} /$ da. Said-Al Ahl et al. (2009) indicated that the essential oil rate is between $0.070-0.072 \mathrm{ml} /$ plant. Our findings are in accordance with the results of Said-Al Ahl et al. (2009).

Tinmaz et al. (2002) identified that the essential oil rate varies between $1-6.1 \%$ on the 0 . vulgare subsp. hirtum samples picked up from the nature, whereas the natural plant samples of Leto and Salomone (1996) include 4\% essential oil. Başer (2001) found a range for the essential oil rate between $1-7 \%$ and 
Oflaz et al. (2002) found 3.6-4.4 \%. They reported a value of $3.9 \%$ for a plant sample from Kaz Mountains. Veres et al. (2003) specified the essential oil rate of $O$. vulgare subsp. hirtum as $4.3 \%$. Oil rate of an individual plant was reported between 1.1$3.2 \%$ by W'glarz et al. (2006).

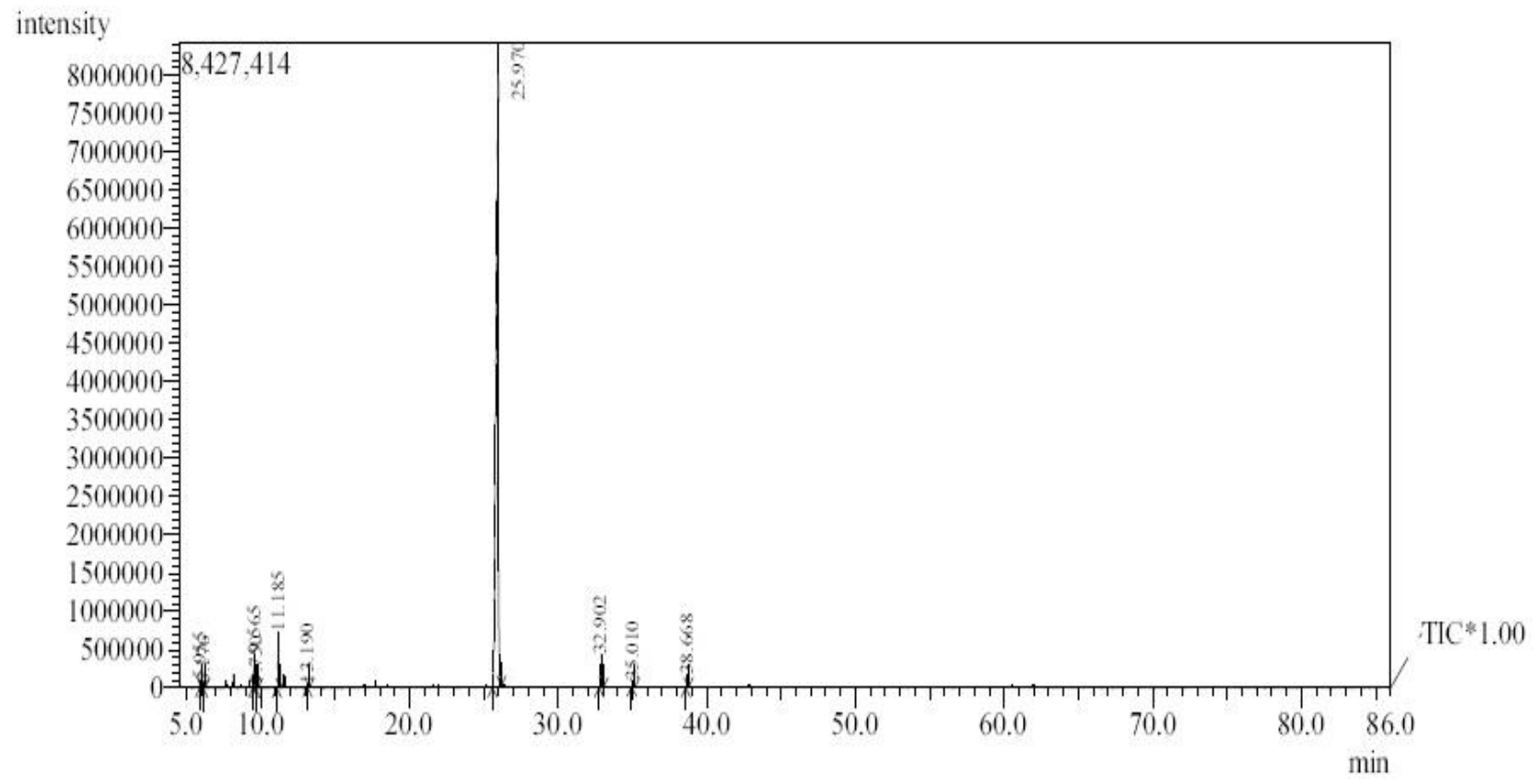

Figure 2. GC / MS Chromatogram of B-413 Clone

Sancaktaroğlu and Bayram (2011) determined the essential oil rate of cultivated plants between 3.78-4.59\%. Karamanos and Sotiropoulou (2013) observed an increase of essentil oil rates which were $1.5 \%$ on the second season and $2 \%$ on the third. Lukas et al. (2015) examined the essential oil content of 502 Origanum vulgare individual plants from 17 different countries and 51 populations and reported that the values varies between $0.03-4.6 \%$. Our findings are considerably higher than the results of the other researchers.

\section{Conclusions}

When all the results are generally evaluated, there was found wide genotypic variation among the examined population. For first year of the study, the values of agronomical features of first harvest were lower than the second and the non-flowering (third) harvest. However maximum essential oil rate values were obtained from the first harvest.
For second year of the study, there were increase on values of plant height, canopy, fresh herb yield, drog herb yield, drog leaves yield and essential oil rate. Differences among genotypes in terms of yield and quality were determined in this study. The population was evaluated in the sense of agronomy and quality and a major variation was observed. According to the results, genotypes with higher yield and essential oil rates have been selected and A clones were created. Among A clones, 20 superior clones were selected for the further studies. It could be possible in the future to complete the breeding circle of clone selection with further studies.

\section{Acknowledgments}

This research was supported by The Scientific and Technological Research Council of Turkey (TÜBITAK Project number: 1130285). This study is part of TUBITAK Project. 


\section{Conflict of Interest}

The authors have declared that they have no conflict of interest.

\section{References}

1. Acikgoz, N., Ilker, E. and Gokcol, A., 2004. Evaluation of biological research on the computer. E.U. TOTEM No:2.

2. Ahmad, S., Kouka, S., Islam, M., Ahmad, K., Aslan, S. Aminullah and Gill, A., 2008. Germplasm evaluation of medicinal and aromatic plants in highland balochistan Pakistan. Pak. J. Bot. 40 (4): 1473-1479.

3. Arabacı, O., Ogretmen, N.G., Aslan, D.F. and Ozcan, I.I., 2012. Ontogenetical Variability of Coridothymus capitatus (L.) Genotypes. 13-15 September. Symposium of Medicinal Plants and Herbs; Tokat.

4. Baser, K.H.C., 2001. Healthy Oregano. Science and Technique. May. 74-77.

5. Bayram, E., Kırıcı, S., Tansı, S., Yılmaz, G., Arabacı, O., Kızıl, S. and Telci, I. 2010. Possibilities to Increase the Production of Medicinal Plants and Herbs. VII. Technical Congress of Agriculturel Engineers Book of Reports 1. Community of Agricultural Engineers. Ozdoğan Press. 437-456.

6. Ceylan, A., Bayram, E., Sahbaz, N., Otan, H. and Karaman, S., 2003. Yield Performance and Essential Oil Composition of Individual Plants and Improved Clones of Origanum onites L. Grown in Aegean Region of Turkey. Israel Journal of Plant Sciences. 51(4):285-290.

7. Hayta, E. and Arabacı, O., 2011. Determination of Different Germination Methods on the Seeds of Some Plants Named as Oregano. Journal of Adnan Menderes University Faculty of Agriculture 8(1):91-101.

8. Karamanos, A.J. and Sotiropoulou, D.E.K., 2013. Field Studies of Nitrogen Application on Greek Oregano (Origanum vulgare subsp. hirtum (Link) Iestwaart) Essential Oil During Two Cultivation Seasons. Industrial Crops and Products 46: 246252.

9. Kokkini, S., 1996. Taxonomy, diversty and distribution of Origanum species. Promoting the conservation and use of under utilized and neglected crops. 14. Oregano. Proceedings of the IPGRI International Workshop on Oregano. 8-12 May. CIHEAM; Valenzano, Bari, Italy.

10. Leto, C. and Salamone, A., 1996. Bio-agronomical Behaviour in Sicilian Origanum ecotypes. Promoting the conservation and use of under utilized and neglected crops. 14. Oregano. Proceedings of the IPGRI International Workshop on Oregano. 8-12 May. CIHEAM; Valenzano, Bari, Italy.
11. Lukas, B., Samuel, R., Mader, E., Baser, K.H.C., Duman, H. and Novak, J., 2013. Complex Evolutionary Relationships in Origanum section Majorana (Lamiaceae). Botanical Journal of the Linnean Society. 171: 667-686.

12. Lukas, B., Schmiderer, C. and Novak, J., 2015. Essential oil diversity of European Origanum vulgare L. (Lamiaceae). Phytochemistry 119:3240.

13. Oflaz, S., Kurkcuoglu, M. and Baser, K.H.C., 2002. Pharmacognosic Researches on Origanum onites and Origanum vulgare subsp. hirtum. 14. Meeting of Medicinal Raw materials. 29-31 May. ISBN 97594077-2, Eskișehir.

14. Said-Al Ahl, H.A.H., Omer, E.A. and Naguib, N.Y., 2009. Effect of Water Stress and Nitrogen Fertilizer on Herb and Essential Oil of Oregano. Int. Agrophysics. 23:269-275.

15. Sancaktaroğlu, S. and Bayram, B., 2011. Researches on Determination of Yield and Quality Characteristics of Different Originated Origanum vulgare subsp. hirtum L. Journal of Ege University Faculty of Agriculture 48 (3): 265-276.

16. SPSS 17.0. 2008. SPSS 17.0 for Windows. Chicago. IL. SPSS Inc.

17. Sezik, E., Tümen, G., Kirimer, N., Ozek, T. and Baser, K.H.C., 1993. Essential Oil Composition of Four Origanum vulgare subspecies of Anatolian Origin. Journal of Essential Oil Research Vol. 5, Iss. 4.

18. Tinmaz, A.B., Kürkcüoglu, M., Baser, K.H.C. and Ozturk, M., 2002. Determination of the Quality Characteristics of Origanum vulgare subsp. hirtum Populations. 14. Meeting of Medicinal Raw materials Reports. 29-31.05.2002. Eskişehir. ISBN: 9759407728.

19. TSI, 2004. Turkish Statistical Institute. Export Statistics, Ankara.

20. Veres, K., Varga, E., Dobos, Á., Hajdú, Z., Máthé, I., Németh, E. and Szabo, K., 2003. Investigation of the Composition and Stability of the Essential Oils of Origanum vulgare ssp. vulgare L. and O. vulgare ssp. hirtum (Link) letswaart. Chromatographia 57 (1):95-98.

21. W'glarz, Z., Osidska, E., Geszprych, A. and Przybyb, J., 2006. Intraspecific Variability of Wild Marjoram (Origanum vulgare L.) Naturally Occurring in Poland. Rev. Bras. Pl. Med. Botucatu. 8:23-26.

22. Wichtl, M., 1971. Die pharmakogostich-Chemische Analyse Band. Frankfurt. pp. 479.

23. Žukauska, I., 2001. Agrobotanical Features and Productivity of Wild and Cultivated Populations of Origanum vulgare. Botany, Acta Biol. Daugavp. 1(2):107-109. 